\title{
Pengutamaan Dimensi Karakter Dalam Pendidikan Agama Kristen
}

\section{Prioritizing Character Dimensions in Christian Religious Education}

\author{
Daniel Nuhamara ${ }^{2}{ }^{*}$ \\ ${ }^{2)}$ Dosen STT Moriah, Tangerang \\ *) Penulis korespodensi: dani.nuhamara@gmail.com \\ Received: 20 December 2017/Revised: 12 February 2018 /Accepted: 19 March 2018
}

\begin{abstract}
Abstrak
Indonesia sedang menjalani suatu gerakan nasional "pembangunan karakter" untuk mengatasi berbagai masalah yang menghambat kesejahteraan masyarakatnya. Semua komponen bangsa dan masyarakat diharapkan memberi kontribusinya. Pendidikan Agama Kristen (PAK) sebagai salah satu tugas gereja yang strategis dapat memberi kontribusinya yang penting bilamana dalam semua program PAK bagi semua kategori usia dan berbagai konteks (keluarga, gereja dan sekolah) dapat mengutamakan dimensi karakter. Penulis membangun argumentasi betapa dekatnya pendidikan karakter dengan PAK, bahkan merupakan bagian integral sebagaimana karakter Kristiani adalah bagian integral dari iman Kristiani. Untuk itu penulis memperjelas konsep-konsep terkait seperti prinsip, nilai, kebajikan, makna hidup, serta karakter dalam upaya membangun argumentasi di atas. Secara spesifik juga konten dari karakter Kristiani dicarikan contoh-contoh Alkitabiahnya.

Kata-kata kunci: prinsip-prinsip, nilai-nilai, kebajikan-kebajikan, makna dan tujuan hidup, PAK, karakter Kristiani, pembangunan.

Indonesia is undergoing a national movement of character building to overcome various problems which hinder the welfare of its society. Every component of the nation and society is expected to give its contribution. Christian Education as one of the strategic tasks or missions of the churches is able to give its significant contribution when its educational programs endeavor to pay more attention to character dimension in its curriculum design for every age category and in all educational contexts. I also argue that character education is closely related to Christian Education even an integral part of it, as Christian character is an integral part of Christian faith. For that purpose I try to clarify some essential concepts such as principles, values, virtues, meaning of life, and Christian character as found in the Bible in order to build on the above argument. Finally, the specific content from the Christian characteristics are found in Biblical examples.
\end{abstract}

Key words: principles, values, virtues, character, Christian virtues, Bible, Christian Education, building. 


\section{Pendahuluan}

Mungkin saja belum semua komponen masyarakat menyadari bahwa bangsa ini telah mencanangkan suatu gerakan nasional "pembangunan karakter (bangsa)" sejak tahun 2010 yang lalu. Hal ini tak berarti bahwa pembangunan karakter merupakan hal baru, karena sejak kemerdekaan dan pada era pemerintahan Soekarno, pembangunan karakter telah dicanangkan dengan istilah "nation and character building." Keterpurukan karakter masyarakat antara lain yang nampak dalam merajalelanya korupsi, politik uang, kekerasan, terkikisnya nilainilai luhur bangsa karena pengaruh asing dan lain-lain, telah membuat "pemerintah mengambil inisiatif untuk memberi perhatian utama kepada pembangunan karakter bangsa. Hal ini tercermin dalam Rencana Pembangunan Jangka Panjang Nasional tahun 2005-2025, yang menempatkan pendidikan karakter sebagai misi pertama dari delapan misi guna mewujudkan visi pembangunan nasional."2 Dalam konteks pendidikan, upaya memberi perhatian lebih kepada aspek karakter tersebut dilakukan dengan menambahkan frasa "budi pekerti" di belakang Pendidikan Agama sehingga menjadi Pendidikan Agama Kristen dan Budi Pekerti, sebagaimana halnya agama-agama lain juga.

Dalam kebijakan nasional tersebut juga dikatakan bahwa gerakan nasional pembangunan karakter ini mempunyai ruang lingkup mulai dari keluarga, satuan pendidikan, pemerintah, masyarakat sipil, masyarakat politik, dunia usaha dan industri, dan media massa. ${ }^{3}$ Ini berarti bahwa hampir semua komponen bangsa dilibatkan dalam gerakan nasional pendidikan karakter demi pembangunan karakter bangsa ini. Walaupun sudah berjalan 5 tahun, tidak ada jaminan bahwa komponen-komponen bangsa tersebut telah menyadari gerakan ini, dan bahwa mereka mempunyai pemahaman yang memadai tentang apa itu karakter serta bagaimana menumbuhkembangkannya.

Tulisan ini ingin memberi kontribusi bagi pendidik dalam PAK apakah di dalam konteks keluarga, komunitas iman Kristen, maupun pada konteks sekolah formal untuk memahami hubungan antara Pendidikan Karakter dan PAK, agar dengan memahami hubungannya mereka dapat dengan sadar ikut serta dalam gerakan nasional ini. Keikutsertaan dalam gerakan pembangunan nasional tersebut antara lain dengan memberi perhatian yang lebih kepada dimensi karakter dari upaya pendidikan agama Kristen baik itu dalam gereja sebagai persekutuan iman, dalam keluarga Kristen, maupun para guru PAK dan Budi Pekerti di sekolah.

${ }^{2}$ Republik Indonesia, Kebijakan Nasional Pembangunan Karakter Bangsa Tahun 20102025 (Jakarta: Kemko Kesejahteraan Rakyat, 2010), i.

${ }^{3}$ Ibid., 5-6. 
Untuk tujuan tersebut maka pendidik dalam komunitas iman Kristen maupun orang tua Kristen serta guru PAK dan Budi Pekerti perlu memahami dengan benar apa itu karakter serta bagaimana kaitannya dengan iman Kristen. Namun suatu tinjauan historis terhadap gerakan ini di negara lain yang menginspirasi gerakan nasional pembangunan karakter bangsa di Indonesia akan juga disinggung, bersamaan dengan sejumlah konsep terkait seperti karakter, prinsip moral atau etika, nilainilai, serta kebajikan (virtues). Hal ini penting agar para pendidik agama baik dalam konteks keluarga, gereja dan sekolah mempunyai pemahaman yang lebih baik mengenai pentingnya pembangunan karakter dalam kerangka tugas mereka.

\section{Bangkitnya Kembali Perhatian Terhadap Pendidikan Karakter}

Apabila diperhatikan dengan saksama daftar rujukan dari naskah akademik pendidikan karakter dan berbagai artikel di Indonesia tentang pendidikan karakter sangat banyak mengacu kepada tulisan para pakar dari Amerika Serikat misalnya saja Thomas Lickona. Bahkan buku-buku karangannya sudah diterjemahkan ke dalam bahasa Indonesia misalnya Character Matters (2004), Educating for Character: How Our School Can Teach Respect and Responsibility (1991). Lickona sendiri telah menulis banyak sekali bukan saja buku tetapi artikel bahkan sejak tahun 1981 ia telah menulis suatu buku berjudul: Raising Good Children from Birth Through the Teenage Years, dengan menggunakan pendekatan perkembangan Moral dari Kohlberg. Semua memperlihatkan dengan jelas pengaruh atau setidaknya inspirasi dari gerakan pendidikan karakter yang terjadi di Amerika Serikat yang sudah mulai sejak tahun 1980-an dan semakin gencar menjelang akhir abad ke XX. Terutama pidato Presiden Clinton pada tanggal 23 Januari 1996 yakni "State of the Union Address" di mana ia mengatakan "I challenge all our schools to teach character education, to teach good values and good citizenship."

Lickona mengatakan sepanjang sejarah dan dalam berbagai budaya di seluruh dunia, pendidikan selalu mempunyai dua tujuan utama: menolong pada nara didik menjadi cerdas dan menjadi baik. Oleh sebab itu, untuk mencapai keduanya mereka membutuhkan karakter. Mereka membutuhkan kualitas karakter seperti etika kerja yang kuat, disiplin diri, dan ketekunan agar supaya mereka dapat melakukan yang terbaik di sekolah dan sukses dalam kehidupan. Mereka juga butuh kualitas karakter seperti respek (menghargai orang lain) dan tanggung jawab agar mempunyai hubungan-hubungan antarpribadi, dan hidup dalam

${ }^{4}$ Kevin Ryan \& Karen E. Bohlin, Building Character in Schools: Practical Ways to Bring Moral Instruction to Life (San Francisco: Jossey Bass, 1999), 189. 
masyarakat. ${ }^{5}$ Selanjutnya ia mengatakan bahwa kembalinya perhatian kepada Pendidikan Karakter khususnya dalam konteks sekolah nampaknya didorong oleh beberapa faktor seperti berikut. Pertama, semakin melemahnya institusi keluarga sebagai suatu tempat sosialisasi nilai moral. Kedua, semakin kuatnya pengaruh budaya media (media culture) sebagai pembentuk nilai-nilai para orang muda. Ketiga, persepsi publik tentang merosotnya moral masyarakat, termasuk kecenderungan orang-orang muda untuk melakukan tindakan-tindakan kriminal, kekerasan, ketidaksopanan, kecurangan/menyontek, materialisme, penggunaan obat-obat terlarang, dan aktivitas seksual di luar nikah. Keempat, kesadaran para pendidik bahwa metode pendidikan nilai yang relativistik - misalnya menyerahkan kepada nara didik untuk membuat keputusannya sendiri tanpa mendasarkannya pada pemahaman akan konten dari karakter sudah jelas merupakan masalah. ${ }^{6} \mathrm{Hal}-\mathrm{hal}$ ini baru menyangkut anak-anak didik di sekolah, namun masih banyak lagi masalah-masalah yang terjadi juga dalam dunia orang dewasa. Apapun penyebab dari masalah-masalah moral sosial kini, dan tak peduli apakah orang mempersepsikan masalah-masalah itu lebih parah kini daripada sebelumnya, "ada kesepakatan luas bahwa pendidikan karakter seharusnya berada pada pusat misi sekolah. Pertanyaannya bagi sekolahsekolah, bukan pada apakah sekolah melaksanakan pendidikan karakter, melainkan bagaimana melakukannya secara efektif."

Tanda-tanda tentang perhatian yang baru terhadap pendidikan karakter dalam konteks Amerika Serikat banyak sekali. Misalnya saja semakin banyak buku dan materi kurikulum pendidikan karakter, dana dari pemerintah federal untuk membiayai pendidikan karakter yang semakin banyak, munculnya kelompok-kelompok advokasi seperti Character Education Partnership (suatu lembaga swasta yang mempunyai banyak sekali aktivitas untuk menunjang pendidikan karakter di sekolah), Character First, adanya pusat-pusat pendidikan karakter di berbagai Perguruan Tinggi (Universitas), jurnal yang memuat hasil penelitian di bidang pendidikan karakter dan masih banyak lagi. ${ }^{8}$ Dengan demikian pendidikan karakter sudah menjadi suatu gerakan nasional yang didukung baik oleh pemerintah federal, maupun lembaga swasta, serta pusat-pusat studi di Universitas. Hal-hal ini hanyalah sekadar contoh apa artinya bahwa pendidikan karakter sudah menjadi suatu gerakan nasional. Walaupun peran keluarga semakin melemah karena

${ }^{5}$ Thomas Lickona \& Mathew Davidson, Character Quotations: Activities That Build Character and Community (San Clemente: Kagan Publishing, 2004), l.

${ }^{6}$ Ibid.,l.

7 Ibid., 2.

${ }^{8}$ Ibid., l. 
berbagai perkembangan, di Amerika Serikat sendiri, pendidikan karakter diakui masih membutuhkan kerjasama dengan keluarga.

Bagaimanakah di Indonesia? Di depan telah dikemukakan bahwa kebijakan pemerintah tentang "nation and character building" sudah dicanangkan oleh Presiden Soekarno. Namun implementasinya belum begitu sistematis dan terencana. Barulah pada zaman presiden Susilo Bambang Yudhoyono, pembangunan karakter menjadi suatu gerakan nasional meskipun masih relatif baru yakni dimulai pada tahun 2010. Dalam pengantar Naskah Akademik Pendidikan Karakter di Perguruan Tinggi, Dirjen Dikti mengatakan bahwa "kami menyadari saat ini bangsa Indonesia tengah menghadapi krisis multidimensional, dan krisis tersebut diyakini bermula dan lemahnya karakter yang dimiliki oleh masyarakat dan bangsa kita. Keadaan ini di satu sisi menunjukkan kurang optimalnya pembentukan karakter yang dilakukan oleh dunia pendidikan, dan di lain sisi merupakan tantangan yang mendorong kita untuk segera berupaya menemukan formulasi, strategi, metode, dan model pembelajaran yang tepat sehingga ke depan, pendidikan karakter lebih efektif." Saya menduga bahwa kebangkitan kembali perhatian terhadap pendidikan karakter dipengaruhi juga oleh apa yang terjadi di Amerika Serikat, atau sekurang-kurangnya terinspirasi dengan perkembangan di sana. Hal ini jelas dari banyaknya rujukan yang digunakan dari sumber-sumber yang berasal dari Amerika Serikat.

Gerakan nasional pembangunan karakter ini diprakarsai oleh pemerintah dan sosialisasinya juga telah dilakukan oleh pemerintah. Secara kurikuler, pemerintah mendorong agar pembangunan karakter dilakukan tidak hanya oleh beberapa mata pelajaran atau mata kuliah saja seperti Pendidikan Kewarganegaraan, Pancasila dan Pendidikan Agama, melainkan untuk semua mata kuliah dengan pendekatan "embedded" dalam arti tidak dijadikan suatu mata pelajaran atau mata kuliah khusus melainkan terjalin dalam setiap mata pelajaran dan mata kuliah. Walaupun demikian diakui bahwa beberapa mata pelajaran atau mata kuliah tertentu seperti Pendidikan Pancasila, Pendidikan Kewarganegaraan, Pendidikan Agama misalnya mempunyai kedudukan khusus dalam rangka implementasi pendidikan karakter karena memang beberapa mata pelajaran atau mata kuliah tersebut sangat dekat bersinggungan dengan pendidikan karakter. Masih banyak lagi langkahlangkah lain yang sedang dan akan dijalankan ke depan.

Di Indonesia, peran keluarga sebagai tempat sosialisasi nilai-nilai moral dan kebajikan (virtues), serta peran komunitas agama masih sangat kuat. Karena itu tulisan ini ingin memberi tekanan pada peranan kedua

\footnotetext{
${ }^{9}$ Direktorat Jenderal Pendidikan Tinggi Kemendiknas, Naskah Akademik Pendidikan Karakter di Perguruan Tinggi (Jakarta: Dirjen Dikti, 2011), i.
} 
institusi tersebut sebagai agen pendidikan karakter yang sangat penting bersama dengan satuan pendidikan formal. Namun sebelum melangkah lebih jauh ada baiknya penulis memaparkan beberapa konsep terkait yang sangat penting.

\section{Beberapa Konsep Penting yang Berhubungan Erat dengan Konsep Karakter}

Kita telah menyebutkan berkali-kali tentang pendidikan karakter, namun apakah karakter itu? Mengapa karakter itu penting baik bagi kehidupan individu maupun sosial? Mengapa karakter dan kebajikan itu sangat esensial dalam menjalani kehidupan iman dan moral Kristiani? Penulis akan mencoba menggali dari berbagai sumber untuk menjawab sejumlah pertanyaan di atas.

David Gill, ahli etika, adalah salah seorang yang dengan teliti mencoba menggali dari berbagai sumber apa itu karakter, juga menunjukkan hubungan antara karakter dengan etika dan iman Kristen. Mengapa kita melakukan hal yang kita lakukan? Ini suatu pertanyaan penting dan kompleks. Pilihan-pilihan kita tentang baik dan buruk mempunyai sejumlah faktor penyumbang: misalnya kondisi mental dan psikologis kita. Kalau kita lagi stres, kita bicara dan bertindak lain dibandingkan pada waktu kita tak stres. Lingkungan sosial banyak berperan dalam keputusan dan tindakan etis kita. Hubungan-hubungan masa lampau kita juga bisa memengaruhi kita, begitu pula orang-orang sekitar kita bisa memberi tekanan atau mendukung, yang pada gilirannya memengaruhi kita. Namun ada juga orang yang berpendapat bahwa suara Tuhan membisikkan kepadanya apa yang harus ia lakukan. ${ }^{10}$

Sebelum kita berbicara lebih jauh tentang karakter, marilah kita mengkaji sejenak beberapa konsep terkait penting berikut ini: prinsipprinsip (principles), nilai-nilai (values) dan kebajikan-kebajikan (virtues). Hal ini penting karena konsep-konsep tersebut erat kaitannya dengan konsep karakter. Pertama, prinsip-prinsip. Bilamana seseorang melakukan sesuatu yang secara moral terpuji atau sebaliknya, maka perhatian kita tertuju kepada prinsip-prinsip moral mereka (apakah tinggi, rendah atau tidak ada). Prinsip-prinsip moral diartikan sebagai pernyataan singkat (brief statement) yang berfungsi sebagai penuntun tindakan yang menentukan hal benar apa yang harus dilakukan (atau sebaliknya yang tak boleh dilakukan). Pada dasarnya prinsip-prinsip bersifat luas, umum dan inklusif - seperti halnya apa yang sering disebut kaidah kencana "Do unto others as you would have them do unto you" (sama

${ }^{10}$ David W. Gill, Becoming Good: Building Moral Character (Downer Grove: InterVarsity Press, 2000), 27. 
seperti engkau suka orang lain perbuat kepadamu, perbuatlah itu kepada orang lain, kata Yesus) (lih. Luk.6:31). Contoh lain adalah "principle of utility" yakni "Do what results in the greatest happiness for the greatest number."1 Saya yakin prinsip tentu berkaitan dengan karakter namun tidak serta merta seseorang yang mengetahui prinsip moral tertentu akan menerapkannya dalam kehidupan konkret. Misalnya saja, mereka yang korupsi atau membunuh orang yang tak berdosa pasti juga tahu perintah jangan mencuri dan jangan membunuh. Karena itu menurut Gill, kalau ada orang yang baik seperti Mother Teresa dan yang lain, mungkin prinsip-prinsip yang baik saja tak cukup menjelaskan mengapa mereka melakukan apa yang dilakukannya. Di mana-mana kita menyaksikan kemerosotan prinsip-prinsip moral dalam berbagai tindakan manusia, namun ada banyak bukti pula bahwa memiliki prinsip-prinsip moral tidak dengan sendirinya akan menuntun kepada pelaksanaannya.

Menurut Gill, ada sesuatu yang lebih mendasar daripada sekadar prinsip-prinsip: yaitu karakter. Prinsip cenderung berada di atas eksistensi kita seperti formula-formula yang terpisah dari diri kita. Namun pada sisi lain, karakter kita selalu ada bersama kita, selalu secara segera hadir dalam situasi apapun. Kekuatan karakter dapat menolong membawa kita melalui situasi-situasi di dalam mana kita tak dapat mengingat suatu prinsip pun. Bill Hybels, seorang pendeta, mengatakan karaktermu adalah "siapa Anda ketika tak seorang pun melihatmu," maksudnya saya kira adalah Anda tetap saja jujur bahkan ketika tak seorang pun tahu apa yang Anda lakukan. Misalnya, karakter kejujuran. Kita baru mengatakan seseorang itu jujur, bukan karena ia tahu dan memiliki prinsip kejujuran, melainkan karena ia mempraktikkan kejujuran dan telah menjadi pola/kebiasaan (habit) hidupnya.

Karakter adalah apa dan siapa kita - apakah orang lain melihat kita atau tidak. Ada macam-macam karakter: fisik, emosional, intelektual. Tetapi bukan ini yang dimaksudkan di sini; yang terutama adalah moral character (karakter moral). Mungkin, suatu latihan yang baik, kalau kita membayangkan apa kata orang kelak pada saat penguburan kita. Bukan gelar, harta yang mereka akan katakan tetapi karakter kita, bahwa kita seorang yang murah hati suka menolong atau orang akan mengatakan kita adalah orang pelit. ${ }^{12}$

Konsep lain yang perlu kita bahas dalam upaya memahami apa itu karakter dan pembentukannya, adalah konsep mengenai nilai-nilai (values). Sekali lagi perhatian kita dalam bagian ini adalah tentang karakter moral dan etis. Suatu cara modern untuk berbicara tentang etika kita adalah bertanya "apa saja nilai-nilai" kita. Apakah yang kita jawab

\footnotetext{
${ }^{11}$ Gill, Becoming Good: Building Moral Character, 27.

${ }^{12}$ Gill, Becoming Good: Building Moral Character, 28.
} 
tentang nilai-nilai kita? Atau, nilai-nilai apa saja yang secara aktual menuntun kita (meskipun implisit dan tidak dianalisis)? Istilah nilai-nilai (values) ini menunjuk kepada fakta bahwa kita menganggap atau memandang atribut-atribut tertentu dari karakter kita "layak" (penting atau bernilai) bagi kita. Tentu saja nilai berkaitan erat dengan karakter, karena karakter tentu didasarkan juga pada nilai-nilai baik yang bersumber dari budaya maupun agama.

Persoalan kita dengan bahasa nilai-nilai (values), bukanlah pada apa yang ia katakan melainkan pada apa yang ia tak katakan. Ia menyungguhkan sisi yang subjektif dari isu (walaupun penting untuk menghargai beberapa atribut karakter), artinya nilai sangat subjektif dan karena itu bisa berbeda-beda antara seseorang dengan orang lain. Untuk itu maka harus ada acuan bersama mengenai nilai apa yang kita anggap baik. Acuannya bisa nillai-nilai yang bersumber dari agama maupun budaya, dan beberapa ahli berpendapat bahwa ciri-ciri (traits) dari karakter yang baik melampaui budaya bahkan agama. Misalnya kejujuran, respek, keadilan (fairness), kerja keras, dll, itu sama saja dalam masyarakat manapun. ${ }^{13}$

Pada masa lalu adalah umum untuk berbicara tentang atribut atau ciri dari karakter yang baik dengan istilah kebajikan (virtues), dan sebaliknya ciri dari karakter yang tidak baik sebagai sifat buruk/jahat (vices). ${ }^{14}$ Virtues berasal dari bahasa Latin Virtus yang secara harfiah berarti sesuatu seperti "power" (kekuatan/kuasa). Virtues pada dasarnya bukan sekadar values (nilai-nilai) yakni ciri-ciri (traits) yang kita rasakan berguna/layak, tetapi kekuatan-kekuatan yang merupakan kemampuan yang riil untuk mencapai sesuatu yang baik. Pertanyaannya adalah "apa saja kekuatan-kekuatan (virtues) yang perlu dikembangkan untuk mencapai suatu kehidupan yang baik? Sebaliknya vices atau sifat buruk adalah kerusakan dari karakter kita yang bertentangan dan merendahkan pencarian akan kehidupan yang baik.

Sebenarnya, menurut Gill, sebelum istilah Latin virtues sudah ada konsep Yunani yang disebut arete (yang oleh orang Romawi diterjemahkan dengan virtus). Karena itulah para filsuf moral menerjemahkan "the ethics of character" (etika karakter) sebagai "aretaic ethics" (etika aretaic). Sedangkan arête dalam bahasa Yunani mungkin paling baik diterjemahkan sebagai "excellence" (keunggulan). Tetapi keunggulan ini bukan keunggulan dalam semua hal, melainkan hanya keunggulan dalam terang tujuan yang sudah ditentukan. Karena itu virtue sebagai arête (keunggulan) merujuk kepada kekuatan-kekuatan dan

\footnotetext{
${ }^{13}$ Gill, Becoming Good: Building Moral Character, 29-30.

${ }^{14}$ Ibid., 30.
} 
kemampuan-kemampuan yang kita miliki - bukan semua kekuatan dan kemampuan, melainkan hanya yang memungkinkan kita mencapai secara unggul tujuan-tujuan kita. Dapat juga dikatakan bahwa virtues seperti itu adalah keterampilan yang dibutuhkan untuk mencapai tugas kehidupan (yang baik).

Ketika kebajikan-kebajikan seperti itu terjalin dalam karakter kita maka hal-hal itu tak menjadi sekadar komponen-komponen "kadangkadang" dalam pengalaman hidup kita, tetapi sudah menjadi kebiasaankebiasaan, kecenderungan-kecenderungan, dan watak-watak yang terusmenerus. Ketika bermacam-macam tantangan muncul, kita tak hanya berkonsultasi dengan prinsip-prinsip dan nilai-nilai, tetapi kita sudah mempunyai kecenderungan dan keinginan untuk bereaksi dengan kebaikan, keadilan, atau dengan kebajikan-kebajikan lain yang tepat kita juga telah memperoleh keterampilan dan kemampuan untuk bertindak dengan cara yang tepat.

Dalam dokumen resmi konferensi Uskup Katolik di Washington DC dikatakan bahwa "a virtue is an habitual and firm disposition to do the good. It allows the person not only toperform good acts, but to give the best of himself." ${ }^{5}$ Virtues jauh lebih dekat dengan karakter (yang baik) dibandingkan dengan prinsip moral maupun nilai-nilai moral, sedangkan karakter itu sendiri sudah menyatu dengan kebajikan-kebajikan moral dalam pengalaman hidup, dan sudah menjadi kebiasaan-kebiasaan, kecenderungankecenderungan, dan watak yang terus-menerus. Itulah sebabnya ada yang mengatakan karaktermu adalah siapa anda sesungguhnya (your character is the real you).

Apakah sesungguhnya karakter itu? Ryan dan Bohlin mengatakan bahwa moral virtues sama dengan character excellence (arête ethike). Mereka juga mencoba dengan cara yang agak berbeda menjelaskan tentang apa itu karakter. Exupery mengatakan "It is only with the heart that one sees rightly; what is essential is invisible to the eye." Dari kutipan itu mereka berdua ingin mengatakan bahwa karakter adalah satu dari hal-hal yang esensial tersebut. Karakter adalah salah satu dari kata-kata yang biasa kita dengar, tetapi yang sulit dijelaskan. Seperti halnya semua hal abstrak; kita tak bisa melihat, menjamah, maupun merasakannya. Namun bilamana kita berada di dekat seseorang yang mempunyai karakter yang baik, kita bisa menyadarinya. ${ }^{16}$

Kata "character" dalam bahasa Inggris berasal dari bahasa Yunani charassein yang berarti "mengukir, memahat" seperti halnya dalam lempengan lilin, batu permata, atau permukaan logam. Dari akar kata

${ }^{15}$ Rediscover, What is Virtues? Why it is Important in Christian Life (Washington DC: United States Conference of Catholic Bishop, 2006), 1.

${ }^{16}$ Ryan \& Bohlin, Building Character in Schools, 5. 
tersebut berkembanglah arti karakter sebagai suatu tanda atau petunjuk yang khusus, dan dari situ bertumbuhlah konsepsi bahwa karakter adalah "pola perilaku individu ... yakni keadaan moralnya. Setiap manusia ditandai oleh berbagai campuran khas antara hal-hal negatif, kesabaran, kelambanan, keprihatinan, kebaikan dan sejenisnya. Namun menurut Ryan dan Bohlin, suatu karakter yang sudah tetap - misalnya karakter yang baik - jauh melebihi sekadar pola perilaku dan kebiasaan bertindak yang tetap.

Karakter yang baik adalah tentang "mengetahui apa yang baik, mencintai yang baik dan melakukan apa yang baik." 17 Ketiganya secara dekat berhubungan. Kita lahir dengan orientasi yang berpusat pada diri sendiri, dan tak tahu apa-apa, di mana dorongan-dorongan primitif kita menguasai penalaran kita. Semua upaya pendidikan dan pengasuhan adalah untuk membawa kecenderungan, perasaan, dan cita-cita dalam harmoni dengan penalaran.

Mengetahui yang baik mencakup tibanya seseorang pada pemahaman akan yang baik dan jahat. Itu berarti mengembangkan kemampuan untuk menilai situasi, dan secara sadar memilih hal yang benar untuk dilakukan dan melakukannya. Inilah yang disebut Aristoteles sebagai penalaran praktis (practical reason). Ini tak hanya bijaksana mengatur waktu tetapi juga menentukan prioritas dan memilih dengan baik dalam semua bidang kehidupan.

Mencintai yang baik berarti mengembangkan suatu perasaan dan emosi moral yang penuh, termasuk mencintai apa yang baik tetapi membenci yang jahat, termasuk suatu kemampuan untuk berempati dengan orang lain. Ini adalah masalah menyukai untuk melakukan yang baik. Mencintai yang baik memungkinkan kita menghargai dan mengasihi, meski kita tahu tindakan-tindakannya salah. Ia mengizinkan kita mencintai orang yang berdosa dan membenci dosanya.

Melakukan yang baik berarti, bahwa setelah pertimbangan yang teliti dan sungguh-sungguh atas semua keadaan dan fakta-fakta yang relevan, kita mempunyai kemauan untuk berbuat/bertindak. Dunia kita penuh dengan orang-orang yang tahu hal benar, apa yang harus dilakukan, tetapi kurang sekali kemauan untuk melakukannya. Mereka tahu apa yang baik, tetapi tak dapat menghantar mereka kepada melakukan yang baik.

Atas dasar pemahaman yang telah diuraikan di atas, maka berikut ini penulis akan mengutip pengertian dari konsep-konsep penting sebagaimana dituangkan dalam naskah resmi Kebijakan Nasional Pembangunan Karakter Bangsa tahun 2010-2025.

${ }^{17}$ Ryan \& Bohlin, Building Character in Schools, 5. 
Karakter adalah nilai-nilai yang khas baik (tahu nilai kebaikan, mau berbuat baik, nyata berkehidupan baik, dan berdampak baik terhadap lingkungan) yang terpateri dalam diri dan terejawantahkan dalam perilaku. Karakter secara koheren memancar dari hasil olah pikir, olah hati, olah raga, serta olah rasa dan karsa seseorang atau sekelompok orang. Karakter merupakan ciri khas seseorang atau sekelompok orang yang mengandung nilai, kemampuan, kapasitas moral, dan ketegaran dalam menghadapi kesulitan dan tantangan. ${ }^{18}$

Dari kutipan ini jelas bahwa para penyusun naskah akademik mengenai gerakan nasional pembangunan karakter bangsa terinspirasi dari tulisan-tulisan yang lahir dalam konteks Amerika Serikat.

Selanjutnya karakter bangsa diartikan sebagai "kualitas perilaku kolektif kebangsaan yang khas-baik yang tercermin dalam kesadaran, pemahaman, rasa, karsa, dan perilaku berbangsa dan bernegara sebagai hasil olah pikir, olah hati, olah rasa dan karsa, serta olah raga seseorang atau sekelompok orang. Karakter bangsa Indonesia akan menentukan perilaku kolektif kebangsaan Indonesia yang khas - baik yang tercermin dalam kesadaran, pemahaman, rasa, karsa, dan perilaku berbangsa dan bernegara Indonesia yang berdasarkan nilai-nilai Pancasila, norma UUD 1945, keberagaman dengan prinsip Bhineka Tunggal Ika, dan komitmen terhadap NKRI."19

Tentu saja definisi di atas terkesan sangat kompleks, namun pertanyaannya yang perlu dijawab adalah apakah yang baik? Apakah yang baik dalam kaitannya dengan karakter itu terkait dengan agama atau budaya tertentu saja, dan karenanya menjadi bervariasi antara satu masyarakat dengan masyarakat yang lain? Ataukah yang baik dalam kaitannya dengan karakter itu melampaui batas budaya dan agama, walaupun setiap orang bisa menghubungkannya dengan agama dan budaya? Saya lebih setuju dengan yang kedua, dan adalah sah-sah saja mengaitkan ciri dari karakter yang baik itu dengan agama atau iman seseorang maupun budayanya. Dengan kata lain kebajikan yang menjadi ciri karakter seseorang bisa saja bersumber dari keyakinan iman (agama) seseorang, dan bisa juga dari budaya, dan keduanya tak bertentangan, yang pertama lebih luas dari yang kedua.

\section{Sumber Norma dari Konten Karakter (Character Traits)}

Pertanyaan pokok dalam pembahasan tentang karakter adalah: apakah yang baik itu? Darimana sumber norma untuk menilai mengenai

${ }^{18}$ Republik Indonesia, Kebijakan Nasional Pembangunan Karakter Bangsa Tahun 20102025 (Jakarta: Kemko Kesejahteraan Rakyat, 2010), 7.

${ }^{19}$ Ibid., 7. 
apa yang baik dan sebaliknya? Umumnya diakui ada dua sumber utama dari ukuran mengenai apa yang baik. Seperti dalam etika, ada etika teologis dan ada etika filosofis. Etika teologis adalah etika yang sumber normanya dipercayai berasal dari Tuhan atau yang dianggap Tuhan, sedangkan etika filosofis berpendapat bahwa sumber normanya berasal dari hasil penalaran filsafati manusia, atau kontrak sosial suatu masyarakat dan hal ini termasuk budaya suatu masyarakat. Perhatian kita hanya terfokus pada yang pertama, karena kita sedang membahas hubungan pendidikan karakter dengan pendidikan agama Kristen.

Dokumen dari Rediscover yakni dari Conference of Catholic Bishop of Washington DC, membagi dua virtues, yakni Human Virtues dan Theological Virtues (kebajikan-kebajikan manusiawi dan kebajikan-kebajikan teologis). Human Virtues menurut dokumen tersebut antara lain belas kasih, rasa tanggung jawab, disiplin dan pengendalian diri, kejujuran, kesetiaan, persahabatan, keberanian, dan ketekunan adalah sekadar contoh saja dari sejumlah kebajikan untuk mempertahankan kehidupan moral/etis. Secara historis, kebajikan-kebajikan manusiawi dikelompokkan atau terhubung dengan kebajikan-kebajikan utama (Cardinal Virtues). Cardinal Virtues terdiri dari prudence (kehati-hatian), keadilan, keuletan, dan kesederhanaan. Tiap kebajikan yang telah disebutkan di atas terhubung dengan salah satu dari kebajikan utama tadi.

Pada pihak lain, dokumen tersebut menjelaskan bahwa Theological Virtues (kebajikan-kebajikan teologis) terdiri dari iman, pengharapan dan kasih (charity) yang dipercayai berasal langsung dari Tuhan melalui peristiwa baptisan; kebajikan teologis itu ditanamkan dalam diri manusia sebagai karunia Tuhan. Kebajikan teologis mendorong kita untuk hidup dalam hubungan dengan Allah Tritunggal. Iman, pengharapan dan kasih memengaruhi kebajikan-kebajikan manusiawi dengan menambahkan stabilitas dan kekuatannya untuk hidup kita. ${ }^{20}$ Pada bagian sebelumnya dikatakan bahwa walaupun Human Virtues didapatkan melalui keinginan manusia yang kuat untuk memperolehnya, karena anugerah Allah yang dikaruniakan kepada manusia akan memurnikan dan menguatkan kebajikan-kebajikan manusiawi kita, sebab pertumbuhan dalam kebajikan-kebajikan tersebut dapat saja dihalangi oleh kenyataan dosa manusia. Khususnya melalui doa dan sakramen, kita membuka diri terhadap karunia Roh Kudus, dan anugerah Allah sebagai cara lain untuk bertumbuh dalam kebajikan.21

${ }^{20}$ Rediscover, What is Virtues? Why it is Important in Christian Life (Washington DC: United States Conference of Catholic Bishop, 2006), 2.

${ }^{21}$ Rediscover, What is Virtues? Why it is Important in Christian Life, 2. 
Kebajikan sangat erat terkait dengan karakter. Dalam Kekristenan, kebajikan itu sangat penting, sehingga ada yang mengatakan bahwa "kehidupan moral Kristen adalah sesuatu yang berusaha mencari dan menumbuhkembangkan dan mempraktikkan kebajikan-kebajikan (virtues)."22 "Kebajikan adalah suatu kebiasaan dan kecenderungan kuat untuk melakukan yang baik. Ia memungkinkan seseorang tidak saja melakukan tindakan yang baik, tetapi memberi yang terbaik dari dirinya. Suatu kehidupan moral yang efektif menuntut praktik dari kebajikan manusia dan teologis." 23

Pandangan dari pihak Protestan tidaklah seragam. Namun mereka sepakat bahwa yang baik adalah yang dikehendaki Tuhan. Hal ini penting, karena tanpa kejelasan mengenai apa yang baik, maka nilai-nilai pribadi serta kemampuan untuk menunjukkan empati hanyalah bersifat palsu. Tetapi apakah yang dikehendaki Tuhan? Umumnya juga mereka sepakat bahwa yang dikehendaki Tuhan dinyatakan dalam diri Tuhan Yesus dan firman Allah (Alkitab) Perjanjian Lama maupun Perjanjian Baru. Dalam etika juga, pertanyaan pokoknya adalah apa baik, benar, bertanggung jawab.

Maka secara lebih rinci David Gill mengatakan bahwa penuntun kita adalah pertama, suatu etika yang berpusat pada Tuhan Yesus. Mengapa? Karena kehidupan Kristen adalah kehidupan yang mengikuti Yesus baik melalui cara hidup-Nya maupun ajaran-Nya. Kedua, dituntun oleh Alkitab, artinya kehidupan dan ajaran Yesus ditemukan dalam Alkitab termasuk Perjanjian Lama yang perlu dibaca dari perspektif ajaran Yesus. Ketiga, diinformasikan oleh gereja sebagai komunitas iman yang bersama-sama menggumuli apa yang baik dan dikehendaki Tuhan untuk dilakukan. Yang keempat adalah bahwa yang baik itu harus dipraktikkan dalam dunia ini dalam situasi yang konkrit. ${ }^{24}$

Selanjutnya menurut Gill, ada tiga tujuan atau manfaat dari etika Kristen. Yang pertama, hal itu baik bagi Anda/penganutnya, karena ia menuntun Anda dengan cara sedemikian rupa sehingga berbahagia karena menemukan makna dan arti kehidupan. Memang ini bukan satu-satunya alasan, tetapi tetap sah dan penting. Tuhan Yesus berfirman, Aku datang agar mereka mempunyai hidup, dan mempunyainya dalam kelimpahan (Yoh. 10:10). Dalam kata-kata "berbahagialah kamu" (beatitudes), bukan saja bahagia dalam arti perasaan emosi yang positif, namun berbahagia dalam arti "a state of well-being"; suatu kebahagian untuk menjadi orang yang rendah hati, murah hati, suci hati, (Mat. 5:12). Yang kedua, adalah baik untuk sesama. Manakala kita berjalan dengan peta etika Kristen,

\footnotetext{
${ }^{22}$ Rediscover, What is Virtues? Why it is Important in Christian Life, 1.

${ }^{23}$ Ibid., 1.

${ }^{24}$ Gill, Doing Right: Practicing Ethical Prinsiples, 31-38.
} 
maka ada manfaat dan kegunaannya bagi sesama dan bangsa-bangsa sekitar. Karena dengan menerapkan prinsip etika Kristen, kita menjadi garam yang mencegah kebusukan dalam masyarakat, dan kita menjadi terang yang memberi kondisi untuk visi dan pertumbuhan dalam dunia. Jadi tidak hanya memberikan berkat pribadi bagi pengikut-Nya. Tujuan yang ketiga, agar Allah dimuliakan. Tuhan Yesus mengatakan bahwa ketika orang lain melihat perbuatan baik kita, mereka akan memuliakan Bapamu yang di Surga (Mat. 5:16). Ketika dekat ajal-Nya, Ia berdoa "Aku memuliakan Dikau di dunia dengan menyelesaikan pekerjaan yang Engkau tugaskan bagi-Ku untuk dikerjakan" (Yoh. 17: 4). Demikianpun dengan kita, ketika kita melakukan apa yang dikehendaki-Nya yakni yang baik, maka kita memuliakan dan menyenangkan Tuhan.

Satu hal yang membedakan karakter dan kebajikan yang bersumber dari agama dan budaya adalah bahwa kita melakukan yang baik sebagai orang percaya bukan supaya orang lain tahu kita baik, namun terutama karena Tuhan pencipta dan pemilik hidup kita menghendakinya. Karena itu etika Kristen termasuk etika karakter/kebajikan (character/virtues ethics) diperkuat oleh hubungan perjanjian dengan Tuhan. Hubungan pribadi dan komunal dengan Tuhan mendasari keseluruhan etika. Penuntun tindakan etis Kristen bukan hanya aturan-aturan abstrak atau prinsip yang otonom, tetapi hubungan dengan yang memberi perintah, norma, dan kebajikan. Motivasi utama dari upaya-upaya/tindakan etis kita seharusnya untuk memuliakan Allah. Tetapi kesetiaan terhadap suatu etika Kristen pada saat yang sama juga baik buat kita dan sesama kita. ${ }^{25}$

Ryan dan Bollin menambahkan bahwa terpisah dari suatu konsepsi tentang tujuan hidup, maka kebajikan tak lebih dari ideal-ideal yang muluk-muluk, tapi hampa akan makna. ${ }^{26}$ "Apakah tujuan hidup manusia? Inilah pertanyaan yang sudah digumuli sejak lama dan jawabannya bervariasi. Dari perspektif iman Kristiani jelas, bahwa tujuan hidup manusia adalah sebagaimana dimaksudkan oleh Sang Khalik, yakni untuk memuliakan Tuhan. Hal itu diwujudkan dengan melakukan apa yang baik sebagaimana Tuhan menghendakinya.

Penulis berpendapat bahwa inti dari kehendak Tuhan adalah "kasih" atau mengasihi karena itulah hukum utama dan pertama. Apa artinya itu? Tentu saja masih membutuhkan penjelasan. Bisa juga kita katakan bahwa hukum kasih yakni "mengasihi Tuhan Allah dan mengasihi sesama seperti mengasihi diri sendiri" (lih. Mat. 22:37-40) adalah prinsip utama dan terdalam. Hal ini masih bisa dijabarkan secara lebih spesifik seperti dalam kata-kata Tuhan Yesus dalam Lukas 6:31 yang

${ }^{25}$ Gill, Doing Right: Practicing Ethical Prinsiples, 41-43.

${ }^{26}$ Ryan \& Bohlin, Building Character in Schools, 43. 
mengatakan: "sama seperti kamu suka orang lain perbuat kepadamu, maka perbuatlah itu kepada orang lain." Inilah yang kita sebut "golden rule" (golden principle). Kaidah kencana serta hukum utama ini perlu dijabarkan dalam sejumlah kebajikan yang kemudian menjadi ciri dari karakter Kristen (character traits). Itulah sebabnya Victor Frankl dapat mengatakan "We must never forget that we may also find meaning in life even when confronted with a hopeless situation, when facing a fate that cannot be changed."27 Ketika ia kembali ke kehidupan biasa setelah meringkuk di kamp kerja yang sangat tak manusiawi, ia menggunakan kekuatan yang ia dapatkan melalui kamp kerja itu, untuk menghibur para pasien, dan menunjukkan kepada mereka bagaimana menemukan makna hidup melalui mengasihi orang lain, melalui pekerjaan, melalui penderitaan, dan dengan jalan melayani Tuhan. ${ }^{28}$

Berbicara tentang ciri karakter (character traits) bisa saja banyak pendapat yang berbeda-beda. Tapi dalam dunia pendidikan di AS umumnya mereka sepakat bahwa ada 6 tiang atau pilar dari ciri karakter yang baik yakni: bisa dipercaya (trustworthiness), menghargai (respect), tanggung jawab (responsibility), adil dan jujur (fairness), kepedulian (caring), dan kewarganegaraan (citizenship). Tak perlu penulis jelaskan makna dari tiap-tiap konten dari karakter ini. Dari keenam pilar (fondasi) masih banyak lagi turunannya. Lickona malah mengatakan bahwa ada 10 kebajikan esensial (essential virtues), dan masing-masing ada penjabarannya. ${ }^{29}$ Menarik bahwa dari kesepuluh kebajikan esensial dan turunannya sangat sejalan dengan kebajikan-kebajikan yang kita temukan dalam Alkitab.

Sama halnya di Indonesia disepakati bahwa ciri karakter bangsa yang bersumber dari Pancasila, UUD 45 dan budaya bangsa ada berjumlah 18 ciri karakter dan ciri karakter ini mengatasi budaya dan agama, namun tidak bertentangan dengan agama manapun. Bahkan ciri karakter yang bersumber dari agama masih jauh lebih banyak dan luas lagi. Penggalian ciri karakter/kebajikan dalam Alkitab sangat banyak, misalnya buah roh seperti dinyatakan dalam Galatia 5:22-23 yang mengatakan: "tetapi buah Roh ialah: kasih, sukacita, damaisejahtera, kesabaran, kemurahan, kebaikan, kesetiaan, kelemahlembutan dan penguasaan diri." Ini baru dari satu sumber, dan sumber-sumber lain dari Alkitab masih banyak lagi. Hal ini menunjukkan kaitan antara iman dan kebajikan-kebajikan, yakni bahwa sejumlah kebajikan yang merupakan buah Roh adalah hasil dari kualitas iman dan kerohanian kita. Tuhan Yesus mengatakan "Akulah pokok anggur dan kamulah ranting-rantingnya. Barangsiapa tinggal

\footnotetext{
${ }^{27}$ Ryan \& Bohlin, Building Character in Schools, 3.

${ }^{28}$ Ibid., 2.

${ }^{29}$ Lickona, Character Matters, 226.
} 
dalam Aku dan Aku dalam dia, ia berbuah banyak, sebab di luar Aku kamu tak dapat berbuat apa-apa." (Yoh. 15:5). Tinggalah dalam Aku dan Aku dalam engkau, karena di luar Aku kamu tak dapat berbuah, sama seperti carang anggur tak dapat berbuah kalau tak melekat pada pokok anggur yang benar. (bnd. Yohanes 15: 4). Yang dimaksudkan berbuah di sini adalah mengasihi dengan benar, dan kasih masih bisa dijabarkan seperti buah Roh dalam Galatia 5:22-23.

Gill misalnya menegaskan perlunya memahami konsep "hati" di dalam Alkitab. Bagi mereka yang percaya akan Alkitab sebagai Firman Tuhan, maka "hati" adalah pusat yang mengontrol kehidupan seseorang. Tuhan Yesus mengatakan, "sebab dari dalam, dari hati orang timbul segala pikiran jahat, percabulan, pencurian, pembunuhan, perzinahan, keserakahan, kejahatan, kelicikan, hawa nafsu, iri hati, hujat, kesombongan, kebebalan. Semua hal jahat ini timbul dari dalam dan menajiskan orang (lih. Markus 7:21-23). Ini adalah ciri dari vice (kejahatan) sebagai lawan dari virtues (kebajikan-kebajikan). Karena itu, kita butuh hati yang baru, cara pandang baru, yang berasal dari Allah dan diasuh oleh firman-Nya serta didukung oleh komunitas orang berkarakter baik, sehingga seseorang terbangun karakter Kristianinya.

Hati kita adalah hakikat paling inti dari keberadaan kita, dari jiwa kita, dan menjadi pusat yang mengontrol karakter kita. Ia menjadi sumber mata air dari motivasi-motivasi dan perilaku kita. Dalam membangun dan membangun kembali karakter kita, maka ia harus terkait dengan hati baru, dan hidup baru yang dijanjikan Allah. ${ }^{30}$

\section{Pendidikan Karakter dalam Pendidikan Agama Kristen}

Pada bagian ini fokus kita adalah hubungan pendidikan karakter dan pendidikan agama, atau bagaimanakah pendidikan karakter dalam pendidikan agama Kristen. Sudah banyak hal dibahas berkaitan dengan perlunya karakter dalam kehidupan individu maupun masyarakat. Bahkan dalam organisasi bisnis atau perusahaan telah pula mengutamakan pembangunan kultur berkarakter dan mengembangkan karakter para pimpinan dan pekerjanya sebagaimana halnya dalam "Character First". Kita juga telah membahas konsep-konsep kunci tentang karakter serta sejumlah konsep terkait seperti prinsip etis/moral, nilainilai moral, dan kebajikan-kebajikan. Pertanyaannya adalah bagaimana membangun karakter? Pertanyaan ini menghantar kita kepada pembahasan pendidikan karakter, karena pembangunan karakter adalah melalui pendidikan karakter.

${ }^{30}$ Gill, Becoming Good: Building Moral Character, 31. 
Pendidikan karakter adalah upaya sadar dan sistematis dan berkelanjutan untuk membangun karakter (yang baik) dalam diri nara didik (anak, remaja, pemuda dan orang dewasa) agar para nara didik mengetahui apa yang baik (dimensi kognitif), mencintai apa yang baik (dimensi afektif), dan melakukan yang baik dalam kehidupan (aspek psikomotorik dan perilaku). Mengapa tak cukup mengetahui dan mencintai yang baik? Karena karakter adalah kualitas-kualitas yang terbangun dalam kehidupan seseorang yang menentukan responsnya tak peduli keadaannya. Bisa juga dikatakan, bahwa karakter itu adalah motivasi dari dalam diri seseorang untuk melakukan apa yang benar/baik menurut standar perilaku tertinggi dalam setiap situasi. Keduanya menekankan tindakan atau respons kita yang didorong oleh kualitaskualitas tertentu atau motivasi batin. Itulah yang kita sebut kebajikankebajikan yang telah menyatu dengan diri kita yang menuntun kita melakukan yang baik itu.

Ryan dan Bohlin berpendapat bahwa pendidikan karakter (dalam konteks sekolah) adalah upaya menolong para nara didik untuk mengetahui yang baik, mencintai apa yang baik, dan melakukan yang baik (knowing the good, loving the good and doing the good). Pada dasarnya upaya tersebut tak lain adalah untuk menolong para nara didik menjadi dewasa dalam pribadi yang berintegritas, cerdas dan mempunyai karakter moral. Adalah perlu bagi para nara didik untuk bergumul dengan dan memahami apa yang baik, yakni apa yang sesungguhnya benar dan layak dalam kehidupan. Untuk melakukan hal ini perlu menolong mereka mengembangkan pengetahuan tentang yang baik dan menilai secara cerdas, sehingga mereka dapat belajar memilih dengan baik di antara berbagai pilihan atau opsi yang saling bertentangan dan menarik dalam kehidupan. Tetapi secara simultan perlu menolong para nara didik mencintai yang baik dalam arti prihatin dengan kebutuhan orang lain, setia kepada komitmennya, suatu tugas yang dikerjakan dengan baik, persahabatan yang baik dan sehat, serta kebiasaan-kebiasaan untuk mempertahankannya. Dengan kata lain mencintai yang baik adalah tentang mendidik perasaan dan kecintaan/kegemaran (passion), sehingga mereka mencintai hal yang benar dan untuk alasan yang benar pula.

Sebagai manusia motivasi kita sering sekali bercampur aduk, sehingga mencintai yang baik adalah salah satu cara untuk menyadari serta memperbaikinya, sehinga menjadi mesin penggerak dari perkembangan moral kita. Sebab kedewasaan moral pada akhirnya adalah bagaimana menuju ke kehidupan yang baik. Untuk mencapai ini maka kita harus bertindak, atau memenuhi kewajiban kita. Karena itu dalam pendidikan karakter ini, para nara didik harus ditolong untuk melihat 
bahwa melakukan yang baik adalah tujuan akhirnya. ${ }^{31}$ Dengan memahami apa itu pendidikan karakter dan tujuannya, maka jelaslah bahwa pendidikan karakter tidak sekadar transmisi pengetahuan saja, tetapi suatu proses yang lebih dalam dan kompleks, yang memungkinkan mereka menyukai dan mencintai apa yang baik misalnya dengan melihat teladan serta pengaruh dari lingkungan sosial (kultur sekolah, keluarga dan komunitas iman) serta adanya kesempatan membiasakan karakter tersebut, seperti kepedulian kepada kebutuhan sesama. Itulah sebabnya dalam konteks sekolah ada program yang disebut "service learning" di mana nara didik diberi kesempatan melayani dan belajar kebiasaan tersebut yang kemudian menjadi kebiasaanya (habit). Di sinilah karakter terbangun dan terbentuk.

Pengertian Pendidikan Agama Kristen (PAK) adalah suatu upaya yang sadar, sistematis, dan berkesinambungan untuk menumbuhkembangkan iman Kristiani dalam diri warga komunitas imannya dalam berbagai kategori usia (mulai dari bayi sampai dengan lanjut usia) baik itu dalam konteks keluarga, komunitas iman, dan sekolah formal (bila dimungkinkan oleh UU negaranya). Dalam konteks Indonesia hal ini adalah wajib belajar agama di sekolah baik swasta maupun negeri karena menjadi mata pelajaran dan mata kuliah wajib.

Thomas Groome mengatakan bahwa hakikat dan tujuan PAK "mengharuskan kita memajukan kesadaran pribadi (personal cognition) sebagai suatu proses reflektif, dialektis dan dialogis yang kritis yang mendorong suatu 'hubungan yang benar' antara yang mengetahui dan yang diketahui dalam suatu komunitas wacana, dan bahwa kita perlu memperluas perhatian kita melampaui sekadar kognisi saja."32 Selanjutnya ia memperjelas apa yang ia maksudkan dengan mengatakan bahwa "prinsip inkarnasi yang merupakan pusat dari Kekristenan menuntut suatu pedagogi yang didasarkan pada dan membentuk diri manusia yang ontik (ontic self) - yakni identitas dan peragenannya di dalam dunia. Contohnya, tujuan kita tak hanya agar mereka tahu tentang keadilan tetapi agar mereka menjadi orang yang adil, bukan hanya mengetahui tentang belas kasih, tetapi menjadi orang yang berbelaskasih." 33 Maksud Groome adalah bahwa kita perlu memberi perhatian kepada semua dimensi kemanusiaan dan mengartikulasikan fondasi filosofis yang paling mendasar serta tugas kita ini sebagai ontologis dan bukan sekadar epistemologis. Atas dasar itu Groome mengusulkan kombinasi epistemologis dan ontologis dengan istilah

\footnotetext{
${ }^{31}$ Ryan \& Bohlin, Building Character in Schools, 46.

32 Thomas H. Groome, Sharing Faith: A Comprehensive Approach to Religious Education e Pastoral Ministry (San Francisco: Harper Collin, 1991), 8.

${ }^{33}$ Ibid., 8.
} 
ontology epistemis (epistemic ontology) untuk merefleksikan kepentingan kependidikannya dan juga keyakinan sentralnya bahwa epistemologi dan ontologi, mengetahui dan keberadaan seharusnya disatukan dalam fondasi filosofis dari PAK.

Meskipun bagi Groome keberadaan (ontology) tetap adalah kata benda dan menjadi fokus, namun epistemis pengubah (modifier epistemic) merefleksikan kepentingan dari pendidik dalam memampukan manusia memberi perhatian kepada kesadaran yang timbul dari keseluruhan keberadaan manusia sebagai agen-subjek dalam hubungan. Ia dengan sadar menggunakan istilah "agen-subjek dalam hubungan" untuk menunjukkan bahwa "keberadaan manusia yang otentik" selalu direalisasikan dalam hubungan dengan orang lain dalam waktu dan tempat. Manusia karenanya mencapai subjektivitasnya yang otentik dengan cara peduli terhadap dan menerima kepedulian dari orang lain. ${ }^{34}$

Atas dasar pergeseran fondasi filosofis itulah maka tujuan PAK bagi Groome adalah conation ${ }^{35}$ yakni suatu istilah kuno dengan alasan karena ia mempunyai arti holistik dibandingkan dengan istilah-istilah lain. Semua pendidikan tentu saja mempunyai tujuan berupa hasil belajar tertentu. Kalau pendidikan itu termasuk pendidikan agama Kristen didasarkan pada ontologi epistemis, dan memperlakukan nara didik sebagai agensubjek dalam hubungan maka hasil belajar yang hendak dicapai mestinya lebih dari sekadar pengetahuan atau kognisi. Karena itulah dengan sadar ia mengatakan bahwa conation adalah istilah yang lebih konprehensif dibandingkan dengan kognisi, dan karenanya lebih memadai untuk menamai hasil belajar yang dituju oleh PAK. Conation (kebijaksanaan) didefinisikan sebagai "apa yang diwujudkan ketika keseluruhan keberadaan nara didik yang ontologis sebagai agen-subjek dalam hubungan secara aktif terlibat dalam mengetahui, menginginkan, dan melakukan apa yang paling memanusiakan manusia (humanisasi) dan memberi kehidupan (i.e. kebenaran) bagi semua. ${ }^{36}$

Memang penjelasan Groome sangat rumit dari segi bahasa, namun sebenarnya dapat disederhanakan. Pertama, bahwa tujuan pendidikan agama haruslah ditujukan kepada manusia seutuhnya sebagai subjek tetapi juga agen dalam relasinya dengan pihak lain. Untuk itu maka Groome mencari dasar filosofis yang solid yakni pada ontologi epistemologis, dan bukan sekadar epistemologis sebagaimana biasanya

${ }^{34}$ Groome, Sharing Faith: A Comprehensive Approach to Religious Education e Pastoral Ministry, 9.

${ }^{35}$ Suatu istilah yang sulit diterjemahkan baik dalam bahasa Inggris dan Indonesia jadi dipakai sebagaimana aslinya dari Bahasa Yunani.

${ }^{36}$ Groome, Sharing Faith: A Comprehensive Approach to Religious Education \& Pastoral Ministry, 9. 
dalam setiap pendidikan. Namun karena kemanusiaan yang otentik hanya bisa dicapai dalam hubungan dengan orang lain, maka hasil belajar yang hendak dicapai dalam PAK adalah conation (kebijaksanaan) yakni bahwa nara didik mengetahui, mencintai atau ingin dan melakukan yang benar. Yang benar itu bisa disebut sebagai segala sesuatu yang memanusiakan manusia dan memberi kehidupan. Dalam bukunya yang terdahulu, tujuan segera PAK adalah menuntun nara didik kepada iman Kristiani baik dalam pengetahuan, sikap dan nilai-nilai, serta perilaku atau tindakannya. ${ }^{37}$

Di manakah hubungan antara pendidikan karakter dan PAK? Baik Ryan dan Bohlin meringkaskan karakter (yang baik) adalah merupakan kebiasaan pikiran (habit of the mind), dan kebiasaan hati (habit of the heart), serta kebiasaan dari tindakan (habit of the action). Kebiasaan-kebiasaan ini dibangun melalui pendidikan karakter baik melalui pengajaran, contoh dan pembiasaan melakukan yang baik. Ryan dan Bohlin, maka Groome juga dengan bahasa yang mirip mengatakan bahwa PAK adalah usaha sadar untuk mewariskan pengetahuan, sikap dan nilai, serta perilaku Kristiani yakni apa yang baik yang sesuai dengan kehendak Tuhan. Jadi sudah jelas kaitannya, walaupun PAK mungkin lebih luas dari sekadar membangun karakter Kristiani, namun karakter Kristiani sangat esensial dalam PAK karena iman tanpa perbuatan adalah mati.

Saya berpendapat bahwa karakter yang baik bersifat lintas agama dan budaya, karena itu PAK bisa juga dilakukan secara lintas iman dan budaya dalam rangka membangun karakter yang baik, sebab karakter yang baik sangat berguna dan penting baik bagi individu dan masyarakat apalagi dalam masyarakat majemuk seperti Indonesia. PAK inter-kultur dan inter-religious bisa dilakukan dengan tujuan yang khusus dan bukan untuk menggantikan PAK bagi dan untuk komunitas iman Kristiani.

Karena karakter Kristiani adalah hal yang integral dalam iman Kristiani, maka sudah waktunya kita mengarus-utamakan pendidikan karakter untuk membangun karakter Kristiani dalam PAK dan tidak menghabiskan waktu untuk menguasai dogma-dogma Kristiani walau elemen-elemen dogma juga penting.

Hal ini pulalah yang mendasari kebijakan Kurikulum 13 di mana mata pelajaran agama ditambahkan dengan Budi Pekerti, sehingga Pendidikan Agama Kristen dan Budi Pekerti, demikian dengan pendidikan agama yang lain. Yang dimaksudkan pemerintah pada waktu itu adalah untuk memberi tekanan pada aspek karakter (akhlak mulia) kepada pendidikan agama agar tidak hanya fokus pada ajaran/doktrin kepercayaan saja. Dengan kata lain, pemberian nama Pendidikan Agama dan Budi Pekerti hendak menekankan perlunya pendidikan agama

${ }^{37}$ Bandingkan dengan Groome, Christian Religious Education, 56-77. 
dilakukan dengan orientasi kepada karakter, atau dalam bahasa yang lebih keren "pengarus-utamaan (main streaming) karakter (kebajikan) dalam pendidikan agama termasuk dalam Pendidikan Agama Kristen.

\section{Kesimpulan}

N. T. Wright menulis suatu buku dengan judul After You Believe Why Character Matters beragumentasi betapa pentingnya karakter Kristiani bagi orang percaya, dan itu bukan hanya tambahan, karena memang iman tanpa perbuatan adalah iman yang mati. Jadi karakter adalah bagian integral dari apa artinya menjadi percaya. Lagi pula para filsuf Yunani seperti Heraclitus telah mengatakan: "Character is your destiny. Character shapes the destiny of an individual person. It shapes the destiny of a whole society." 38 Jadi karakter penting bagi seorang yang mengaku Kristen dan bahkan penting sebagai nasib dari seseorang individu dan suatu masyarakat. Aristoteles seperti dikutip oleh Lickona mengatakan bahwa "A fulfilling life is a life of virtue. You can't be happy unless you're good." 39 Karakter bahkan penting untuk mencapai tujuan hidup, yakni kebahagian.

Kalau bangsa ini sedang menggalakkan pembangunan karakter bangsa untuk mengatasi keterpurukannya, maka pertanyaannya, apa sumbangan PAK bagi pembangunan karakter bangsa? Saya berpendapat, bahwa dengan pengarus-utamaan pembangunan karakter (Kristiani) melalui PAK sangat perlu khususnya dalam merancang dan mengembangkan kurikulum PAK baik konteks sekolah, komunitas iman Kristen maupun keluarga Kristen. Gereja perlu memberdayakan keluargakeluarga Kristen agar menjadi pendidik karakter bagi anak-anaknya, karena dalam konteks keluargalah terjadi pembiasaan dari karakter yang baik. Demikian gereja sebagai komunitas iman perlu menjadi komunitas berkarakter agar dapat menjadi garam dan terang dunia, dan menjadi komunitas teladan. Khotbah-khotbah minggu maupun program-program pendidikannya untuk semua kategori usia perlu memberi perhatian utama kepada aspek karakter dari iman Kristiani dan tidak berkutat pada dogma saja.

Dalam rangka penyempurnaan Standar Isi berbagai mata pelajaran di Pendidikan Dasar dan Menengah di mana penulis terlibat sebagai salah satu anggota tim ahli BSNP (Badan Standar Nasional Pendidikan), maka pemberian tempat yang utama kepada aspek karakter tersebut telah diupayakan dalam Standar Isi PAK dan Budi Pekerti, sebagaimana juga Pendidikan Agama yang lain di samping doktrin, ibadah dan sejarah. Bahkan pada aspek historis, tokoh-tokoh historis baik dalam Alkitab

${ }^{38}$ Lickona, Character Matters, 4.

${ }^{39}$ Lickona, Character Matters, 7. 
maupun sejarah gereja diangkat sejauh memberi contoh karakter Kristen yang hendak dibahas. Bersamaan dengan itu pendidikan agama diarahkan untuk menghindari radikalisme sehingga nara didik mencintai tanah air Indonesia yang berdasarkan Pancasila, UUD 45, Bhineka Tunggal Ika, dan NKRI. Jadi menghargai perbedaan baik itu dari sudut agama, budaya, suku dan ras adalah karakter bangsa yang perlu ditumbuhkembangkan.

Hanya dengan cara itu maka PAK memberi sumbangan yang berarti bagi pembangunan bangsa antara lain melalui pembangunan karakter yang sedang menjadi suatu gerakan nasional di dalam bangsa ini.

\section{Kepustakaan}

Direktorat Jenderal Pendidikan Tinggi Kemendiknas. Naskah Akademik Pendidikan Karakter di Perguruan Tinggi. Jakarta: Dirjen Dikti, 2011.

Gill, David W. Becoming Good: Building Moral Character. Downer Grove: Inter-Varsity Press, 2000.

. Doing Right: Practicing Ethical Principles. Downer Grove: InterVaristy Press, 2004.

Groome, Thomas H. Christian Religious Education. San Francisco: Harper and Row, 1981.

Sharing Faith: A Comprehensive Approach to Religious Education \& Pastoral Ministry. San Francisco: Harper \& Collin, 1991.

Lickona, Thomas. Character Matter: How to Help Our Children Develop Good Judgment, Integrity, and Other Essential Virtues. New York: Touchstone, 2004.

. Raising Good Children. New York: Bantam Book, 1983.

Lickona, Thomas \& Mathew Davidson. Character Quotation: Activities that Build Character and Community. San Clemente: Kagan Publishing, 2004.

Republik Indonesia. Kebijakan Nasional Pembangunan Karakter Bangsa Tahun 2010-2025. Jakarta: Kemko Kesejahteraan Rayat, 2010.

Miller, Christian B. dkk. Character: New Directions from Philosophy, Psychology, and Theology. Oxford: Oxford University Press, 2015.

Ryan, Kevin \& Karen E. Bohlin. Building Character in Schools: Practical Ways to Bring Moral Instruction to Life. San Francisco: Jossey -Bass, 1999.

Rediscover. What is Virtues? Why it is Important in Christian Life. Washington DC: United States Conference of Catholic Bishop, 2006. 